\title{
CHARACTERISTICS OF HIPROLY BARLEY II. QUANTIFICATION OF TWO PROTEINS CONTRIBUTING TO ITS HIGH LYSINE CONTENT
}

\author{
by
}

\author{
IB JONASSEN
}

\author{
Department of Biotechnology, Carlsberg Research Laboratory, \\ Gamle Carlsberg Vej 10, DK-2500 Copenhagen Valby \\ and \\ Institute of Genetics, University of Copenhagen, \\ Oster Farimagsgade 2 A, DK-1353 Copenhagen K
}

Keywords: Albumin, globulin, single radial immunodiffusion, protein composition

Quantitative extraction of salt and water soluble proteins from Hiproly, CI 4362 and Bomi barley was performed and their content of the lysine rich SP II albumin determined by a single radial immunodiffusion assay. The elevated content of SP II albumin in Hiproly accounted for $37 \%$ of the difference in crude protein lysine between Hiproly and Bomi and for $19 \%$ between Hiproly and its low lysine sisterline CI 4362. Apart from the lysine rich SP II albumin, other proteins contribute to the high lysine content of Hiproly.

The single radial immunodiffusion assay for quantitative determination of SP II albumin permits the separation of high-lysine from low-lysine lines in progenies from crosses with Hiproly. Identification of plants carrying the Hiproly gene can be carried out by single seed analysis and is more reliable than identification by $\beta$ amylase content or by dye-binding capacity measurements. Degree of grain hardness as measured by energy required for milling can vary independently of the content of SP II albumin.

\section{INTRODUCTION}

Studies of the albumin proteins extracted from Hiproly grains identified two lysine rich albumin polypeptides (14). They have been designated SP II A and SP II B and were also found to be notably rich in valine, glutamine/glutamic acid and asparagine/aspartic acid. Immunologically the two proteins are very similar if not identical and therefore the SP II B polypeptide with a molecular weight of 8,100 dalton is considered a fragment of the SP II A peptide with a molecular weight of 9,100 dalton. 
In this paper a quantitative analysis of the amount of the two lysine rich albumin proteins in the grains of Bomi and Hiproly barley and in those of Hiproly's low-lysine sisterline CI 4362 is presented. This permits decision as to whether the high-lysine content of Hiproly is due to a high content of these two proteins. In addition various high- and low-lysine barley lines were analysed in order to study to what extent the lysine content is correlated with the amount of the two lysine rich albumin proteins. A radial immunodiffusion assay was developed for the quantitative determination of the SP II A and SP II B proteins. This allows to screen for the amount of these two proteins on a single kernel basis.

\section{MATERIALS AND METHODS}

\subsection{Plant material}

The 36 barley lines examined (Table I) included 14 commercial barley varieties grown at Carlsberg's Research Farm, Allindemaglegård, in 1976. The residual 22 lines were part of Carlsberg Plant Breeding's high-lysine barley nursery. Hiproly and CI 4362 were harvested in 1978 at Carlsberg's Research Farm, Hyldager- gård. 6 lines originated from the Swedish Seed Association, Svalof, Sweden, and consisted of homozygous lines from the crosses listed in Table I. These lines were grown at Hyldagergård in 1976. The residual 14 lines were grown at Hyldagergárd and comprised repeated backcrosses of different commercial barley varieties with Hiproly. 12 of the lines were grown in 1975 and 2 lines in 1976.

\subsection{Extraction of the water- and salt-soluble protein fraction of the grain}

Barley flour was obtained by grinding in a Cyclotec sample mill (Udy Analyser Company, Boulder, Colorado, USA) using a $1 \mathrm{~mm}$ screen.

\subsubsection{Extraction procedure for screening}

Duplicate samples of barley flour $(2 \mathrm{~g})$ were extracted for 1 hour at room temperature by shaking (Rotamix, Heto, Birkerød, Denmark) with $20 \mathrm{ml}$ of a $0.5 \mathrm{~m}-\mathrm{NaCl}$ solution in a $29 \mathrm{~mm}$ diameter, round bottomed centrifuge tubes. The extracts were clarified by centrifugation $(27.000$ $\times \mathrm{g}$ for $25 \mathrm{~min}$ ), and the volume of each extract was measured after decantation. Samples from

\section{Table I}

List of barley lines examined.

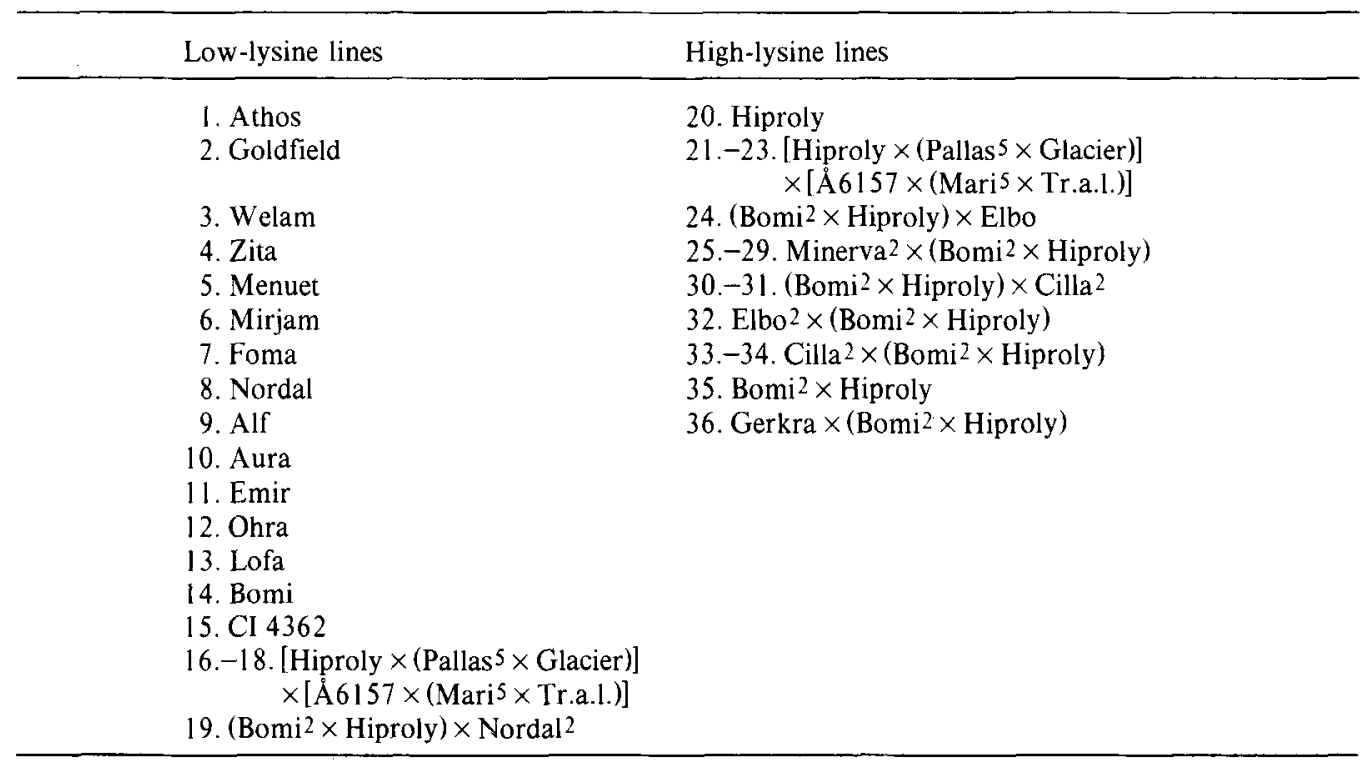


each extract were taken for further analysis, and the residual extracts dried in an oven at $110^{\circ} \mathrm{C}$ for Kjeldahl determinations.

\subsubsection{Quantitative extraction of the water-and salt-soluble protein of barley}

Four successive extractions (12) of Hiproly, CI 4362 and Bomi were carried out as described in section 2.2.1. Samples for analysis were taken after each round of extraction. The four flour extracts from each barley line were pooled and dried in an oven at $110^{\circ} \mathrm{C}$ for Kjeldahl analysis.

\subsubsection{Extraction procedure for single seed analysis}

The extraction method applied was essentially the one described by Aastrup (1). Kernels were ground individually in a mill, and the flour was weighed into plastic tubes. The flour was suspended in $0.5 \mathrm{M}-\mathrm{NaCl}$ solution $(0.01 \mathrm{ml}$ per mg flour), and the tubes were shaken for one hour. The flour was removed by centrifugation, and $0.005 \mathrm{ml}$ samples were taken for analysis.

\subsection{Amino acid analysis}

Amino acid analysis was performed both on crude- and salt-soluble barley protein. All samples were analysed on a Durrum D-500 amino acid analyser. Cysteine and tryptophane were not determined.

\subsubsection{Amino acid analysis of the crude barley protein}

Duplicate samples of $50 \mathrm{mg}$ accurately weighed barley flour were hydrolysed in $5 \mathrm{ml} 6$ $\mathrm{N}-\mathrm{HCl}, \quad 0.05 \% \mathrm{w} / \mathrm{v}$ phenol and $0.001 \mathrm{M}-$ norleucine for 24 hours at $110^{\circ} \mathrm{C}$ in evacuated ampoules. Values for the amino acid composition of the crude protein are expressed as $g$ amino acid per $100 \mathrm{~g}$ protein (Kjeldahl $\mathrm{N} \times$ 6.25 ), and the average of double determinations is given.

\subsubsection{Amino acid analysis of the water-and salt-soluble protein of barley}

Duplicate samples of $0.050 \mathrm{ml}$ salt extract (section 2.2.1) were lyophilized and hydrolysed in $0.200 \mathrm{ml} 6 \mathrm{~N} \mathrm{HCl}$ containing $0.05 \% \mathrm{w} / \mathrm{v}$ phenol for 24 hours at $110^{\circ} \mathrm{C}$ in evacuated ampoules.

\subsection{Quantification of SP II albumin by single radial immunodiffusion}

Rabbit antisera, raised against the two highlysine albumin proteins of Hiproly barley (SP II

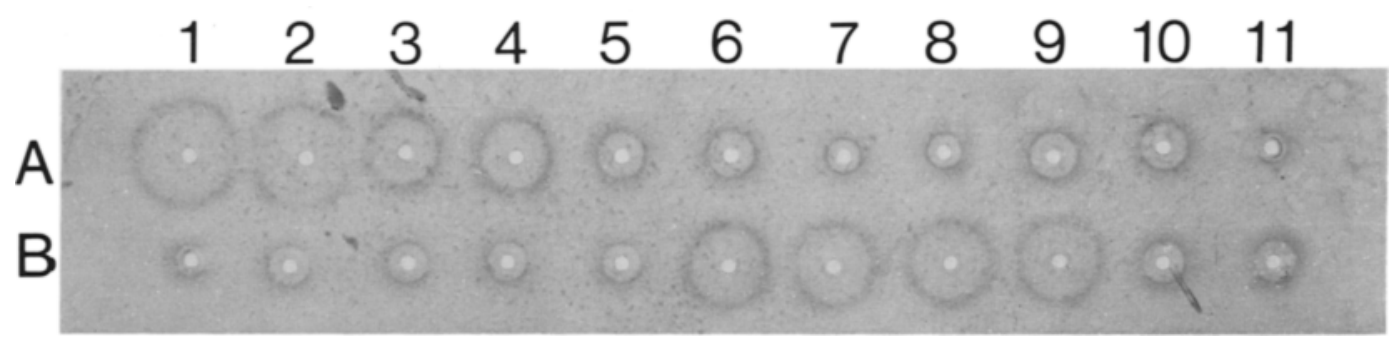

Figure I. Quantification of SP II albumin by means of radial immunodiffusion.

The area of the circles is directly proportional to the amount of SP II albumin applied in the sample well (5 $\mu$ ).

Key to wells:

$2.05 \mu \mathrm{g}$ SP II albumin A 1,2

$1.03 \mu \mathrm{g}$ SP II albumin A 3,4

$0.53 \mu \mathrm{g}$ SP II albumin A 5,6

$0.26 \mu \mathrm{g}$ SP II albumin A 7,8

Crude extract of Hiproly B 6-9

Crude extract of CI 4362 B 2-5

Crude extract of low-lysine lines A 11, B 1

Crude extract of high-lysine lines from crosses with Hiproly A 9, 10, B 10, 11 
A and SP II B protein) as described by JONASSEN (14), were used in this study. The method of single radial immunodiffusion by MANCINI et al. (15) was modified as follows: A $1 \% \mathrm{w} / \mathrm{v}$ buffered agar solution was obtained by boiling 1 $\mathrm{g}$ of agar (type HSA from Litex, Postbox 7, 2600 Glostrup, Denmark) in tris-barbital buffer, $\mathrm{pH}$ $8.6(0.073 \mathrm{M}$-tris, $0.0245 \mathrm{~m}$-barbital, $0.00036 \mathrm{~m}$ calciumlactate, $\mathrm{pH}$ 8.6). The agar solution was cooled down to $57^{\circ} \mathrm{C}$ in a water bath, and 0.6 $\mathrm{ml}$ of a 10 times concentrated and purified antiserum were mixed $33 \mathrm{ml}$ agar solution and poured in a mould (dimensions, $18.4 \times 10 \times$ $0.15 \mathrm{~cm}$ ). 55 antigen wells (diameter $2.1 \mathrm{~mm}$ ) were punched into each gel plate, and $0.005 \mathrm{ml}$ samples applied (Figure 1). Each gel plate included 4 duplicate standards of purified antigen. All radial immunodiffusion plates were stained by Coomassie Brilliant Blue R 250 (4). The amount of albumin was determined with a calibration curve using known amounts of SP II albumin.

\subsection{Quantification of $\beta$-amylase by rocket immunoelectrophoresis}

Rabbit serum against the salt-soluble extract (albumin and globulin) of barley was obtained and purified as described by HARBOE and INGILD (7).
$0.005 \mathrm{ml}$ diluted samples of barley salt extracts (section 2.2.1) were subjected to rocket immunoelectrophoresis as described by AxELSEN et al. (4). The gels were stained for $\beta$-amylase activity after electrophoresis by the starch-iodine method (8). The $\beta$-amylase content of the different samples was determined by a standard curve obtained from solutions of purified barley $\beta$-amylase.

\subsection{Determination of milling energy}

$5 \mathrm{~g}$ whole grain of each barley sample were ground in a mill, and the required energy was recorded. The method employed was a modified version of the one described by ALLison et al. (2): $5 \mathrm{~g}$ samples were ground by an Alpine Perplex 100 LU mill (Alpine AG, D-89 Augsburg 1, Germany) mounted with a $2 \mathrm{~mm}$ screen. The electric energy required was recorded by a power to voltage converter connected to the mill. The total energy required to mill a sample was estimated by integrating the area of the trace from the recorder chart. The integrations were carried out with a Hewlett Packard digitizer (HP 9864 A) connected to a Hewlett Packard calculator (HP 9825 A).

\section{Table II}

Protein content $(\mathrm{Kjeldahl} \mathrm{N} \times 6.25)$ and lysine content of protein fractions in three barley varieties.

\begin{tabular}{|c|c|c|c|c|c|c|c|c|c|}
\hline \multirow{2}{*}{$\frac{\text { Variety }}{\text { Samples }}$} & \multicolumn{2}{|c|}{ Hiproly CI 4362} & \multirow[t]{2}{*}{ Bomi } & \multicolumn{2}{|c|}{ Hiproly CI 4362} & Bomi & \multicolumn{2}{|c|}{ Hiproly CI 4362} & \multirow[t]{2}{*}{ Bomi } \\
\hline & \multicolumn{2}{|c|}{ Total protein } & & \multicolumn{3}{|c|}{ Salt-soluble protein } & \multicolumn{2}{|c|}{ SP II albumin } & \\
\hline Protein, g per & & & & & & & & & \\
\hline $100 \mathrm{~g}$ dry matter of seeds & 17.3 & 15.3 & 11.7 & 4.77 & 3.85 & 2.94 & 0.284 & 0.077 & 0.012 \\
\hline Lysine mg per & & & & & & & & & \\
\hline $100 \mathrm{~g}$ dry matter of seeds & 650 & 468 & 383 & 266 & 176 & 148 & 33.6 & 9.1 & 1.4 \\
\hline $\mathrm{g}$ lysine per $100 \mathrm{~g}$ protein & 3.76 & 3.06 & 3.27 & 5.59 & 4.59 & 5.05 & $11.84 \mathrm{a})$ & & \\
\hline $\begin{array}{l}\text { Lysine, \% of lysine } \\
\text { in the seed }\end{array}$ & & & & 40.9 & 37.6 & 38.6 & 5.2 & 1.9 & 0.3 \\
\hline $\begin{array}{l}\text { SP II lysine, \% of salt- } \\
\text { soluble lysine }\end{array}$ & & & & & & & 12.6 & 5.1 & 0.9 \\
\hline
\end{tabular}

a) The figure is calculated from the amount of SP II A and SP II B in Hiproly (14). 


\subsection{Determination of the starch-protein adherance character}

10 kernels of each barley line were classified for endosperm type under the microscope, as described by MuNCK et al. (18).

\subsection{Water determination of barley flour}

The water content of barley flour samples was measured as the decrease in weight after 1 hour in an oven at $130^{\circ} \mathrm{C}$.

\subsection{Determination of protein content}

Protein content of barley flour and dried protein extracts (section 2.2) were determined by the Kjeldahl-method using the Tecator System (Tecator, Höganäs, Sweden) with a selenium catalyst (Kjeltabs, Bie and Berntsen, Copenhagen, Denmark). Protein is expressed as Kjeldahl $\mathrm{N} \times 6.25$.

\subsection{Determination of dye-binding capacity}

Duplicate samples of barley flour $(0.5 \mathrm{~g})$ were determined for dye-binding capacity according to the Udy-method (21) using the Tecator System (Tecator, Höganäs, Sweden).

\section{RESULTS AND DISCUSSION}

\subsection{Quantification of SP II albumin in Hiproly, CI 4362, and Bomi barley}

The seed proteins of Hiproly, CI 4362, and Bomi barley were quantitatively extracted in order to determine how much the content of SP II albumin contributes to the amino acid composition of the crude- and salt-soluble protein fraction of the three barley lines. Protein was calculated as Kjeldahl $\mathrm{N} \times 6.25$. The $\mathrm{SP}$ II protein was determined by radial immunodiffusion section 2.4) and calculated as Kjeldahl protein $(\mathrm{N} \times 6.25)$ from the molecular weight and animo acid content (14). It can be calculated from the data in Table II that Hiproly contains 24 times more SP II albumin on a dry matter basis than the commercial barley variety Bomi. The sisterline $\mathrm{CI} 4362$ is intermediate between Bomi and Hiproly, containing 6.4 times more SP II albumin than Bomi and 3.6 times less than Hiproly. The lysine content per $100 \mathrm{~g}$ crude protein of the three barley lines is listed in Table II, and it can be calculated that the elevated content of SP II albumin in Hiproly accounted for $37 \%$ of the difference in lysine content between Bomi and Hiproly and for 19\% between CI 4362 and Hiproly. According to Table II the salt-soluble protein of Hiproly contains $5.59 \mathrm{~g}$ lysine per $100 \mathrm{~g}$ protein. This figure includes a contribution of $0,70 \mathrm{~g}$ lysine from the SP II albumin. The figure for Bomi is $5.05 \mathrm{~g}$ lysine per $100 \mathrm{~g}$ protein and includes a contribution of only $0.05 \mathrm{~g}$ lysine from the SP II albumin. The differences in the lysine content of the salt-soluble proteins among the three varieties are very well correlated with the differences in the lysine content of the total protein. On the other hand, when the difference in lysine content between Hiproly and Bomi are compared with the lysine contribution from the SP II albumins, it is clear that other differences in the composition of the salt-soluble protein must be present among the three lines besides the difference in SP II albumin content. Multiple differences between Hiproly lines and low-lysine barley have been

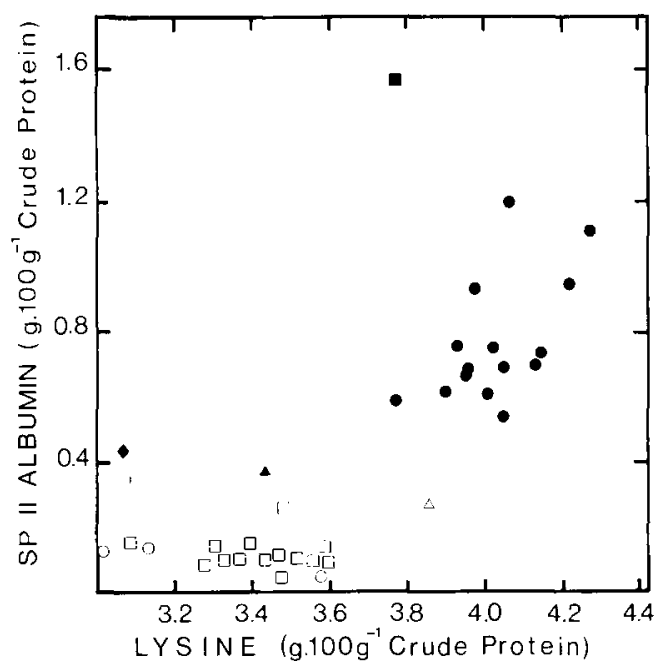

Figure 2. Plot of amount of SP II albumin per $100 \mathrm{~g}$ crude protein versus amount of lysine per $100 \mathrm{~g}$ crude protein in different barley lines.

- Hiproly, $\bullet$ CI 4362, $\square$ commercial barley varieties, - high-lysine lines from crosses with Hiproly, O low-lysine lines from crosses with Hiproly. $\Delta$ line 17, Table I, and $\triangle$ line 36, Table I with plants displaying intermediate values with respect to lysine and SP II albumin content. 
demonstrated in the case of $\beta$-amylase (3) and by several electrophoretic studies $(11,13,17)$. It was pointed out by HAGBERG et al. (6) that the CI 4362, of Ethiopian origin, was morphologically very similar to Hiproly, but that its amino acid composition was very close to that of conventional barley. It was therefore expected that Hiproly and CI 4362 displayed a simple relationship with respect to lysine content, for example that the reduction of SP II albumin in CI 4362 could explain the difference in lysine content. However, CI 4362 contained more SP II albumin than would have been expected from its overall lysine content (Figure 2).

It should be noted that the extractions performed are only quantitative with respect to SP II albumin soluble in $0.05 \mathrm{M}-\mathrm{NaCl}$ solution, and it is possible that residual SP II albumins are bound in the insoluble residue. This question needs further investigation. Determination of SP II albumin by means of single radial immunodiffusion has advantages and limitations. The major advantage is its simplicity, low costs, and the ease with which the method can be applied to mass screening. A major limitation is due to the fact that it becomes increasingly difficult to measure with accuracy the diameter of the precipitate as it diminishes and this will tend to overestimate small precipitates (cf. Figure 1).

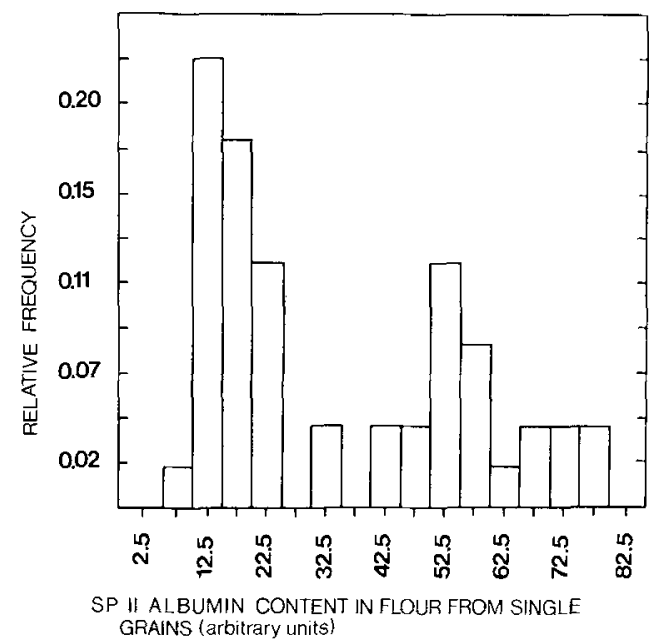

Figure 3. The histogram displays the distribution of the SP II albumin content in 50 seeds from line 17(Table I) (Figure 2, A) derived from a cross with Hiproly.

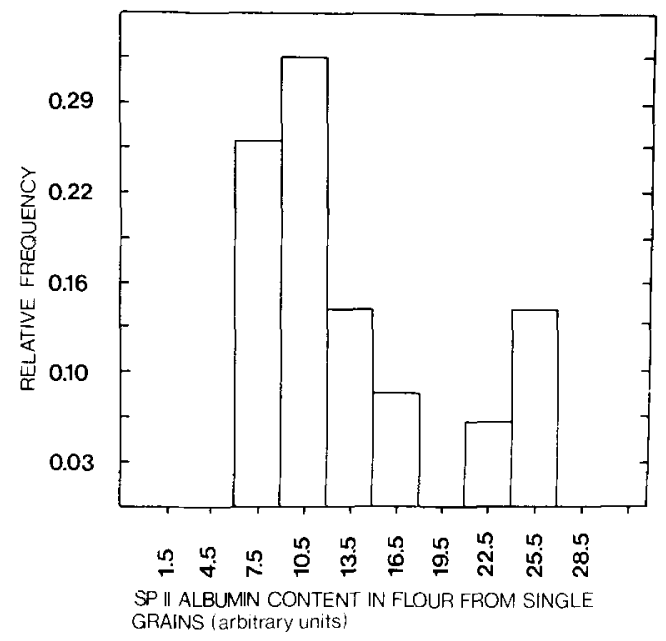

Figure 4. The histogram displays the distribution of the SP II albumin content in 50 seeds from line 36 (Table I) (Figure 2, $\Delta$ ) derived from a cross with Hiproly.

\subsection{Contents of SP II albumin in different barley lines}

In order to determine if the content of SP II albumin is diagnostic for the Hiproly character in many different genetic backgrounds 22 experimental barley lines and 14 commercial varieties were analysed. The barley material was extracted as described in section 2.2.1, and the content of SP II albumin determined by radial immunodiffusion. In Figure 2 the SP II albumin content per $100 \mathrm{~g}$ crude protein of the lines is plotted against their lysine content per $100 \mathrm{~g}$ crude protein. This results in two discrete groups of barley lines. One group is high in lysine (about $4 \mathrm{~g}$ lysine per $100 \mathrm{~g}$ crude protein) and contains more than $0,54 \mathrm{~g} \mathrm{SP}$ II albumin per $100 \mathrm{~g}$ crude protein, whereas the other group is low in lysine (about $3.4 \mathrm{~g}$ lysine per $100 \mathrm{~g}$ crude protein) and contains less than $0.25 \mathrm{~g}$ SP II albumin per 100 g crude protein.

It can be seen that both CI 4362 and Hiproly fall outside these two groups, in fact CI 4362 has a considerable amount of SP II albumin but very little lysine, whereas Hiproly has more SP II albumin than any other investigated line. Two lines derived from crosses with Hiproly fall outside the two groups described above as they have an intermediate lysine and SP II albumin 
content. To investigate the nature of the two lines further, 50 seeds of each line were individually extracted (section 2.2.3.), and the content of SP II albumin per mg seed was determined. The histograms in Figures 3 and 4 show that the two barley lines contained seeds differing significantly in SP II albumin content. The histogram in Figure 3 reveals separated classes of seeds, one class having a high content of SP II albumin and the other a low one. The number of individuals in each class is approximately the same, and since this line has been propagated in bulk for 6 generations it is likely that it was started from a plant heterozygous for the lys gene. The analysis of this line demonstrates that screening for SP II albumin with the

\section{Table III}

Characteristics of barley lines with a low content of SP II albumin versus lines high in SP II albumin.

\begin{tabular}{|c|c|c|c|}
\hline & $\begin{array}{l}\text { Mean and standard } \\
\text { deviation for } 17 \text { lines } \\
\text { containing less than } \\
0.25 \mathrm{~g} \text { SP II albumin } \\
\text { per } 100 \mathrm{~g} \text { crude protein }\end{array}$ & $\begin{array}{l}\text { Mean and standard } \\
\text { deviation for } 15 \text { lines } \\
\text { containing more than } \\
0.54 \mathrm{~g} \text { SP II albumin } \\
\text { per } 100 \mathrm{~g} \text { crude protein }\end{array}$ & \\
\hline $\begin{array}{l}\text { Analysed } \\
\text { character }\end{array}$ & $\bar{X}$ & $\bar{Y}$ & $\bar{X}-\bar{Y}$ t-test \\
\hline $\begin{array}{l}\text { g SP II per } 100 \mathrm{~g} \\
\text { crude protein }\end{array}$ & $0.108 \pm 0.012$ & $0.708 \pm 0.050$ & $-0.600^{* * *}$ \\
\hline $\begin{array}{l}\mathrm{g} \text { lys per } 100 \mathrm{~g} \\
\text { crude protein }\end{array}$ & $3.38 \pm 0.04$ & $4.02 \pm 0.03$ & $-0.64^{* * *}$ \\
\hline $\begin{array}{l}\mathrm{g} \text { lys per } 100 \mathrm{~g} \\
\text { salt protein }\end{array}$ & $4.95 \pm 0.06$ & $5.57 \pm 0.11$ & $-0.62 * * *$ \\
\hline $\begin{array}{l}\mathrm{g} \text { val per } 100 \mathrm{~g} \\
\text { crude protein }\end{array}$ & $5.03 \pm 0.05$ & $5.28 \pm 0.03$ & $-0.25^{* * *}$ \\
\hline $\begin{array}{l}\mathrm{g} \text { val per } 100 \mathrm{~g} \\
\text { salt protein }\end{array}$ & $4.99 \pm 0.05$ & $5.78 \pm 0.11$ & $-0.79 * * *$ \\
\hline $\begin{array}{l}\mathrm{g} \text { arg per } 100 \mathrm{~g} \\
\text { crude protein }\end{array}$ & $4.94 \pm 0.07$ & $5.13 \pm 0.06$ & $-0.19^{*}$ \\
\hline $\begin{array}{l}\mathrm{g} \text { arg per } 100 \mathrm{~g} \\
\text { salt protein }\end{array}$ & $6.65 \pm 0.09$ & $6.31 \pm 0.13$ & $0.34^{*}$ \\
\hline $\begin{array}{l}\mathrm{g} \text { crude protein per } \\
100 \mathrm{~g} \text { dry matter }\end{array}$ & $12.30 \pm 0.22$ & $13.82 \pm 0.46$ & \\
\hline $\begin{array}{l}\mathrm{g} \text { salt protein per } \\
100 \mathrm{~g} \text { dry matter }\end{array}$ & $2.47 \pm 0.04$ & $3.05 \pm 0.10$ & \\
\hline $\begin{array}{l}\text { milling } \\
\text { energy, } \mathrm{cm}^{2}\end{array}$ & $12.86 \pm 0.60$ & $16.45 \pm 0.53$ & \\
\hline $\begin{array}{l}\mathrm{g} \beta \text {-amylase per } \\
100 \mathrm{~g} \text { salt protein }\end{array}$ & $0.692 \pm 0.076$ & $1.560 \pm 0.127$ & \\
\hline
\end{tabular}

${ }^{*}{ }^{*}$ : significance at the $0.01 \%$ level, ${ }^{*}$ : significance at the $5 \%$ level. Salt protein: protein soluble in $0.5 \mathrm{M}-\mathrm{NaCl}$ and expressed as $\mathrm{g} \mathrm{N} \times 6.25$. Milling energy is expressed as trace area required to grind $5 \mathrm{~g}$ of barley seeds. 
immunodiffusion method on single seeds is ideal to select high-lysine segregants in Hiproly crosses.

In spite of the promising results in improving yield of Hiproly genotypes (6), no high yielding high-lysine barley has as yet become available (5). The yield level is restricted by small seed size combined with poor fertility (19). Furthermore, the backcross lines seem to be more sensitive to extreme weather conditions than many high yielding commercial varieties (19). In selecting high-lysine segregants from Hiproly crosses, it appears to be difficult to combine the high-lysine content ( $\mathrm{g}$ per $100 \mathrm{~g}$ protein) with high yield. It will be possible to test this on Hiproly lines with the immunodiffusion assay by rapidly selecting a large number of lines with a high content of this protein.

\subsection{Evaluation of the SP II albumin screening method}

The two lines (Figure 3 and 4) which turned out to be populations of two different SP II albumin genotypes were excluded from this part

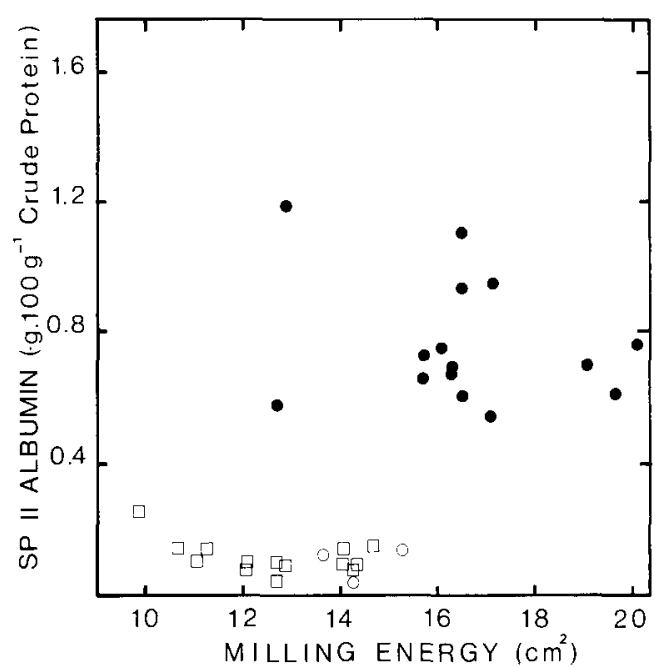

Figure 5. Plot of milling energy versus amount of SP II albumin per $100 \mathrm{~g}$ crude protein.

- High-lysine lines (Table I, 21-35) from crosses with Hiproly. O Low-lysine lines (Table I, 16, 18, 19) from crosses with Hiproly. $\square$ Commercial barley varieties (Table 1-14).

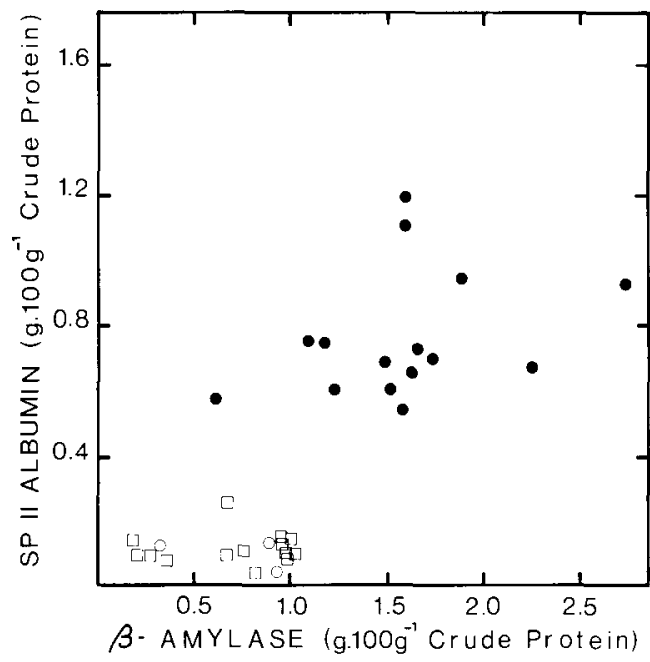

Figure 6. Plot of amounts of $\beta$-amylase per $100 \mathrm{~g}$ crude protein versus amount of SP II albumin per $100 \mathrm{~g}$ crude protein.

- High-lysine lines (Table I, 21-35) from crosses with Hiproly. O Low-lysine lines (Table I, 16, 18, 19) from crosses with Hiproly. $\square$ Commercial barley varieties (Table 1-14).

of the work as well as Hiproly and Cl 4362 and it was deduced from Figure 2 that the remaining high-lysine lines within the given limits were homogeneous with respect to their SP II albumin content. The amount of SP II albumin (g per 100 $\mathrm{g}$ crude protein or salt-soluble protein) was calculated for the remaining lines. The data are presented in Table III. It has been shown that the elevated content of lysine in Hiproly is significantly associated with an increased content of valine and arginine (20). The SP II albumin contains relative large amounts of lysine and valine, (14), and it can therefore be expected that the SP II albumin contributes significantly to the increased content of these amino acids in the high-lysine segregants compared to low-lysine segregants in crosses. The t-test (Table III) shows that the high valine content of the high-lysine lines is significantly associated with a high content of SP II albumin (significance at the $0.01 \%$ level), not only in the salt-soluble protein, but also in the crude protein. On the other hand the increased arginine content of the high-lysine lines cannot be due to a high content 


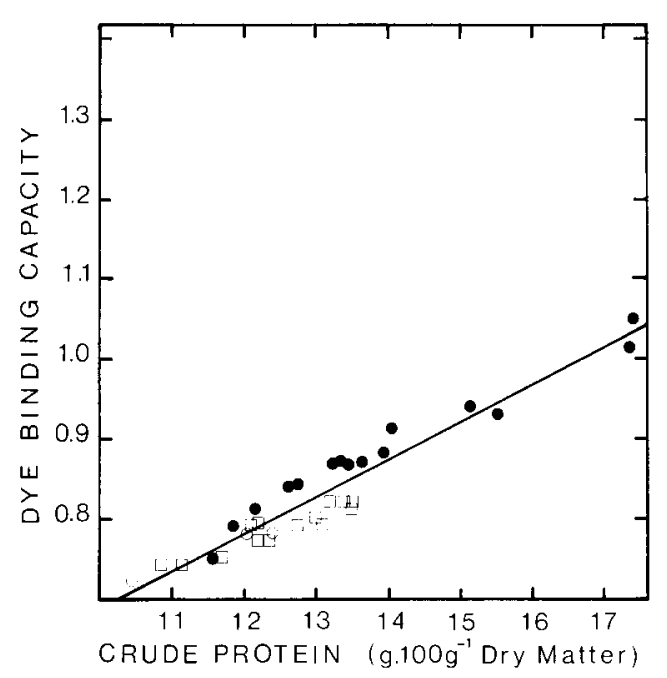

Figure 7. Plot of amounts of crude protein per $100 \mathrm{~g}$ dry matter versus dye-binding capacity.

Crude protein is determined as Kjeldahl $\mathrm{N} \times 6.25$. Dye-binding was measured by the Udy-method (section 2.10). The line of regression is calculated from all points. High-lysine lines (Table I, 21-35) from crosses with Hiproly. O Low-lysine (Table I, $16,18,19)$ from crosses with Hiproly. $\square$ Commercial barley varieties (Table 1-14).

of SP II albumin as its content of arginine is not specifically high.

\subsection{Comparisons between the SP II albumin screening method and other screening methods for the Hiproly character}

Starch-protein adherence has been used as a marker for the Hiproly character $(10,18)$. To investigate if there is a connection between the starch-binding factor and the amount of SP II albumin, 10 seeds from each line were examined for the starch-protein adherence character. All lines containing more than $0.54 \mathrm{~g} \mathrm{SP}$ II albumin per $100 \mathrm{~g}$ crude protein displayed an intermediate starch-binding character when compared to Hiproly barley lines low in SP II albumin. It was not possible to demonstrate a close connection between starch-linking and high amount of SP II albumin content because of the intermediate nature of all high-lysine lines tested. MUNCK (17) has suggested that there might be a connection between the Hiproly character and grain hard- ness. The groups from the starch-binding determinations acted homogeneously when determined for milling energy (Figure 5). However, two lines with more than $0.54 \mathrm{~g}$ SP II albumin per $100 \mathrm{~g}$ crude protein had milling energies comparable to the lines low in SP II albumin (less than $0.25 \mathrm{~g}$ SP II albumin per 100 $g$ crude protein). This indicates that an elevated SP II albumin content does not directly affect grain hardness measured as milling energy.

Hiproly contains large amounts of soluble $\beta$ amylase compared to commercial barley varieties (3) and segregants from Hiproly crosses low in lysine. The screening method of HeJgaARD et al. (9) was used as described in section 2.5, and $\beta$-amylase content was measured and plotted versus SP II albumin content (Figure 6). The $\beta$ amylase quantification method does not give a clear cut separation between the the two groups being high and low in SP II albumin content. It should be noted that an elevated $\beta$-amylase content tends to reduce the overall lysine content of the seeds because of the relatively low lysine content in $\beta$-amylase itself ( 3.9 mole \%).

Dye-binding capacity versus crude protein in dry matter (Figure 7) has been recommended by MossBerg (16) as a screening method for highlysine cereals. It is shown in Figure 7 that the line of regression does not produce a sharp separation between the two SP II albumin groups. This result is not unexpected because the method measures the amount of basic amino acids (16). Determination of the SP II albumin content has given the best separation of the lowfrom the high-lysine lines containing the Hiproly character.

\section{ACKNOWLEDGEMENTS}

I wish to express my sincere gratitude to Dr. L. Munck, Dr. T. Nilsson-TillgReN for support and encouragement. I am most grateful to Professor D. von WetTstein and to my colleague cand. scient STEN AASTRUP for inspiring and fruitful discussions, and to Dr. J. HEJGAARD for providing the barley $\beta$-amylase. I am indebted to MetTe $\mathrm{H} ø$ J for her excellent technical assistance and pleasant collaboration. I wish to thank Bodil CoRneliussen, for performing the amino acid analyses. 


\section{REFERENCES}

1. Aastrup, S.: The relationship between the viscosity of an acid flour extract of barley and its $\beta$-glucan content. Carlsberg Res. Commun. 44, 289-304 (1979)

2. Allison, M. J., I. Cove \& R. Mchale: A rapid test for the prediction of malting quality of barley. J. Inst. Brew. 82, 166-167 (1976)

3. Allison, M. J. \& J. S. Swanston: Relationship between $\beta$-amylase polymorphisms in developing, mature and germinating grains of barley. J. Inst. Brew. 80, 285-291 (1974)

4. Axelsen, N. H., J. Krøll \& B. WeEke (eds.): A manuel of quantitative immunoelectrophoresis. Methods and applications. Universitetsforlaget. Oslo (1973)

5. Garkavy, P. F., A. A. Soziniv, V. D. NavolotSKy, F. A. Poperelya, A. M. Sherement, S. I. Ignatova \& V. P. Netsvetaev: Barley breeding for protein quality. In: Barley genetics III. Proceedings of the third international barley genetics symposium. H. Gaul ed., Verlag Karl Thiemig. München pp. 572-578 (1975)

6. Hagberg, A., K.-E. KarLSSON \& L. MunCK: Use of Hiproly in barley breeding. In: Improving plant proteins by nuclear techniques. IAEA/ FAO STI/PUB 258, Vienna, 121-132 (1970)

7. HaRboe, N. \& A. INGILD: Immunization, isolation of immunoglobulins, estimation of antibody titre. In: A manual of quantitative immunoelectrophoresis. Methods and applications, N. H. Axelsen, J. Krøll \& B. Weeke eds., Universitetsforlaget. Oslo pp. 161-164 (1973)

8. Hejgaard, J.: Free and protein-bound $\beta$-amylases of barley grain. Characterization by twodimensional immunoelectrophoresis. Physiol. Plant. 38, 293-299 (1976)

9. Hejgaard, J., B. Køie, K.-E. Karlsson \& A. TALLberg: $\beta$-amylase activity - a simple screening test in Hiproly barley breeding. Hereditas 90 . 145-147 (1979)
10. Helm, J. H., R. J. Metzer \& W. J. Kronstad: Inheritance of high lysine in Hiproly barley and its association with the Hiproly endosperm gene. Crop Sci. 14, 637-640 (1974)

11. Ingversen, J. \& B. KgiE: Protein patterns of some high lysine barley lines. Hereditas 69. 319-323 (197I)

12. IngVersen, J. \& B. Køie: Lysine rich proteins in the salt-soluble protein fraction of barley. Phytochemistry 12, 73-78 (1973)

13. INGVERSEN, J. \& B. KøIE: Lysine-rich proteins in high-lysine Hordeum vulgare grain. Phytochemistry 12, 1107-1111 (1973)

14. JONASSEN, I.: Characteristics of Hiproly barley I. Isolation and characterisation of two watersoluble high-lysine proteins. Carlsherg Res. Commun. 45, 47-58 (1980)

15. Mancini, G., A. O. Carbonara \& J. F. HEREMANS: Immunochemical quantitation of antigens by single radial immunodiffusion. Immunochemistry 2, 235-254 (1965)

16. Mossberg, R.; Evaluation of protein quality and quantity by dye-binding capacity: A tool in plant breeding. In: New approaches to breeding for improved plant protein (Proc. Panel Röstunga, 1968). IAEA, Vienna 151-160 (1969)

17. MUNCK. L.: Improvement of nutritional value in cereals. Hereditas 72, 1-128 (1972)

18. Munck, L., K.-E. Karisson, A. Hagrerg \& B. O. EgGum: Gene for improved nutritional value in barley seed protein. Science 168, 985-987 (1970)

19. Persson, G. \& K.-E. Karlsson: Progress in breeding for improved nutritive value in barley. Cereal Res. Commun. 5, 169-179 (1977)

20. Pomeranz, Y., D. M. Wesenberg, R. T. Smith. G. S. Robbins \& J. T. Gilbertson: Amino acid composition of barley kernels from different parts of the spike. Cereal Chem. 53, 839-845 (1976)

21. Udy, D. C.: Improved dye method for estimating protein. J. Am Oil Chem. Soc. 48 (1971) 29 A 